\title{
Synthesis, Crystal Structure and Characterization of $\left[\left(\mathrm{CH}_{3} \mathrm{CH}_{2}\right)_{4} \mathrm{~N}\right] \mathrm{Mn}_{1,5} \mathrm{Cl}_{3} 4 \mathrm{H}_{2} \mathrm{O} \mathrm{Cl} 2\left(\mathrm{H}_{2} \mathrm{O}\right)$
}

Ikram DHOUIB*, Philippe GUIONNEAU, Tahar MHIRI and Zakaria ELAOUD

1-Laboratory of Physico-Chemistry of Solid States. LR11 ES51 of Sfax. Road of Soukra km 4. Sfax 3071. Tunisia.

Email: ikramdhouib82@yahoo.fr

2- Institute of Chemistry of Condensed Matter Bordeaux-ICMCB, 87avDrA; Schweitzer, 33608 Pessac Cedex-France

Email: guio@icmcb-bordeaux.cnrs.fr

1-Laboratory of Physico-Chemistry of Solid States. LR11 ES51 of Sfax. Road of Soukra km 4. Sfax 3071. Tunisia.

Email: tahar.mhiri@fss.rnu.tn

1-Laboratory of Physico-Chemistry of Solid States. LR11 ES51 of Sfax. Road of Soukra km 4. Sfax 3071. Tunisia.

Email: zakaria_elaoud@yahoo.com

\begin{abstract}
Single crystals of $\left[\left(\mathrm{CH}_{3} \mathrm{CH}_{2}\right)_{4} \mathrm{~N}\right] \mathrm{Mn}_{1,5} \mathrm{Cl}_{3} 4 \mathrm{H}_{2} \mathrm{O} \mathrm{Cl} 2\left(\mathrm{H}_{2} \mathrm{O}\right)$ were grown by the slow evaporation technique and characterized by means of single-crystal X-ray diffraction, FT-IR and Raman spectroscopy. The title compound belongs to the triclinic space group $P \overline{1}$ with the following unit cell dimensions: $a=7.5425(4) \AA, b=9.8464 \AA, c=13.7671(6) \AA$, $\alpha=89.951(3)^{\circ}, \beta=89.753(3)^{\circ}, y=81.861(3)^{\circ}, Z=4$. These structures have solved using direct methods and refined by leastsquares analysis. The structure was solved by the direct method and refined to final $R$ value of 0.0567 . The projection of $\left[\left(\mathrm{CH}_{3} \mathrm{CH}_{2}\right)_{4} \mathrm{~N}\right] \mathrm{Mn}_{1,5} \mathrm{Cl}_{3} 4 \mathrm{H}_{2} \mathrm{O} \mathrm{Cl} 2\left(\mathrm{H}_{2} \mathrm{O}\right)$ in the plan $(\mathrm{a}, \mathrm{b})$ shows an arrangement in layers perpendicular to the direction $\mathrm{b}$. The structure consists of infinite parallel two-dimensional planes built connected ions and water molecules by strong $\mathrm{O}$ $\mathrm{H} \ldots \mathrm{O}$ and $\mathrm{O}-\mathrm{H} . . . \mathrm{Cl}$ hydrogen bonding.
\end{abstract}

Keywords: Hybrid compound; X-ray diffraction; Infrared spectroscopy; Raman spectroscopy

\section{Council for Innovative Research}

Peer Review Research Publishing System

Journal: Journal of Advances in Chemistry

Vol. 8, No. 2

editor@cirjac.com

www.cirjac.com, member.cirworld.com 


\section{Introduction}

The combination of organic molecules and inorganic materials was the starting point for the development of new hybrid compounds, with expected physical and chemical properties. These compounds have attracted great attention because of their unique opportunity to combine the remarkable features of organic compounds with those of inorganic materials. Their applications have been explored and reported in various fields, such as magnetism, conductive, luminescence and optics [1-5]. The materials based upon substituted complex ammoniums with halogenated metals such as $\mathrm{Hg}, \mathrm{Cd}, \mathrm{Zn}, \mathrm{Mn}$ and Cu etc. present very interesting physical properties [6-12].

On the other hand, hybrid compounds based on tetra-alkylammonium cations of the general formula $\left(\mathrm{C}_{n} \mathrm{H}_{2 n+1}\right)_{4} \mathrm{~N}^{+}$such as $\left(\mathrm{CH}_{3}\right)_{4} \mathrm{~N}^{+},\left(\mathrm{C}_{2} \mathrm{H}_{25}\right)_{4} \mathrm{~N}^{+}$and $\left(\mathrm{C}_{3} \mathrm{H}_{7}\right)_{4} \mathrm{~N}^{+}[10,12,13]$. The specific geometry of these cations can generate supramolecular networks in one, two or three dimensions.

However, in conjunction with some resent works on these hybrids compounds, the crystal structure and vibrational studies of many organic-inorganic crystals have been investigated in our laboratory [14-16]. The present work deals with the growth, single $\mathrm{X}$-ray diffraction (XRD) study and the detailed vibrational spectral analysis of a new organic-inorganic crystal: $\left[\left(\mathrm{CH}_{3} \mathrm{CH}_{2}\right)_{4} \mathrm{~N}\right] \mathrm{Mn}_{1,5} \mathrm{Cl}_{3} 4 \mathrm{H}_{2} \mathrm{O} \mathrm{Cl} 2\left(\mathrm{H}_{2} \mathrm{O}\right)$.

\section{Experiment}

\subsection{Synthesis}

The title compound was prepared by mixing $\left(\mathrm{CH}_{3} \mathrm{CH}_{2}\right)_{4} \mathrm{NOH}(1 \mathrm{mmol}), \mathrm{MnCl}_{2}$. $(2 \mathrm{mmol})$, concentrated $\mathrm{HCl}(1 \mathrm{~mL})$ and water $(10 \mathrm{~mL})$. The mixture was then allowed to stand and evaporate slowly at room temperature. After 3 days, pink crystals appeared and they were studied by single crystal $\mathrm{X}$-ray diffraction. The analysis of the obtained phase confirms the formation of $\left[\left(\mathrm{CH}_{3} \mathrm{CH}_{2}\right)_{4} \mathrm{~N}\right] \mathrm{Mn}_{1,5} \mathrm{Cl}_{3} 4 \mathrm{H}_{2} \mathrm{O} \mathrm{Cl} 2\left(\mathrm{H}_{2} \mathrm{O}\right)$.

\section{2. X-ray collection}

Single-crystal X-ray data of $\left[\left(\mathrm{CH}_{3} \mathrm{CH}_{2}\right)_{4} \mathrm{~N}\right] \mathrm{Mn}_{1,5} \mathrm{Cl}_{3} 4 \mathrm{H}_{2} \mathrm{O} \mathrm{Cl} 2\left(\mathrm{H}_{2} \mathrm{O}\right)$ were collected at room temperature on a Nonius Kappa-CCD diffractometer using Mo-Ka radiation $(\lambda=0.71073 \AA)$ through the program COLLECT [17]. Correction for Lorentz-polarisation effect, peak integration and background determination were carried out with the program DENZO [18]. Frame scaling and unit cell parameters refinement were performed with the program SCALEPACK [18].

Pertinent details of the crystal structure of $\left[\left(\mathrm{CH}_{3} \mathrm{CH}_{2}\right)_{4} \mathrm{~N}\right] \mathrm{Mn}_{1,5} \mathrm{Cl}_{3} 4 \mathrm{H}_{2} \mathrm{O} \mathrm{Cl} 2\left(\mathrm{H}_{2} \mathrm{O}\right)$ are listed in Table 1 . The crystal structure has been solved and refined in the triclinic symmetry, space group $P \overline{1}$, using the WINGX environment [19] and based on SHELXS97 [20] and SHELXL97 [21] softwares. All the hydrogen positions of the diprotonated cation were placed geometrically and held in the riding mode the $\mathrm{C}-\mathrm{H}$ bonds were fixed and $\mathrm{O}$.... $\mathrm{H}$ were affined at 0.96 to $0.97 \AA$ and $0.73(8)$ to $0.95(8) \AA$., respectively). Bond distances and angles calculated from the final atomic coordinates, as well as probable hydrogen bonds, are given in Tables 2, 3 and 4 respectively.

\section{3. Spectroscopic measurements}

The Fourier transform infrared (FT-IR) spectrum of the title compound was recorded in the range $4000-400 \mathrm{~cm}^{-1}$, with samples in KBr pellets using PERKIN-ELMER FT-IR spectrometer. The resolution of the spectrum is $\pm 2 \mathrm{~cm}^{-1}$. The Fourier transform Raman (FT-Raman) spectrum of the same compound was recorded using Horiba Jobin Yvon LabRAM HR 800 Dual Spectrophotometer. The incident laser excitation is $632 \mathrm{~nm}$. The scattered light was collected at the angle of $180^{\circ}$ in the region $3600-50 \mathrm{~cm}^{-1}$ and the resolution was set up to $2 \mathrm{~cm}^{-1}$.

\section{Results and discussion}

\subsection{Refinement of the structure}

The structure of this compound was solved in the triclinic space group P-1, which consists of anionic chains of singly edge-sharing manganese (II) metal centers through chloride atoms. The asymmetric unit (Fig. 1) consists of a single $\mathrm{Mn}(1) \mathrm{Cl} 2 \mathrm{H}_{2} \mathrm{O}$ moiety, $\mathrm{Mn}(2) \mathrm{Cl}_{2} 2 \mathrm{H}_{2} \mathrm{O}$ moiety, two water molecules $2 \mathrm{H}_{2} \mathrm{O}$, a chloride anion $\mathrm{Cl}$ and tetraethylammonium $\left[\left(\mathrm{C}_{2} \mathrm{H}_{5}\right)_{4} \mathrm{~N}\right]$ cation, which under the appropriate symmetry operations yields a molecular structure as shown in figure 2.

The first octahedral $\mathrm{Mn}(1)$ metal center lying in a special position, are coordinated by two chloride atoms symmetry [Cl5, $\mathrm{Cl}^{\mathrm{a}}$; (a) $-\mathrm{x},-\mathrm{y}+2,-\mathrm{z}$ ] and four corners of water molecules (Mn-O vary from 2.205(1) to 2.241 (2)) forming a distorted octahedra geometry (Table 2).

The Monomers octahedral $\mathrm{Mn}(1) \mathrm{Cl}_{2} 2 \mathrm{H}_{2} \mathrm{O}$ are located on planes perpendicular to the $\mathrm{b}$ axis at $\mathrm{z}=0$. Between two successive inorganic layers are interposed a free chlorine atom $\mathrm{Cl}(6)$ and two water molecules.

The second octahedral $\mathrm{Mn}(2)$ metal center is in a general position, it is achieved by means of four bridging chloride atoms, two terminals of $\mathrm{H}_{2} \mathrm{O}$ molecules. The shortest $\mathrm{Mn}$...Mn distance in the molecule chain is $3.733 \AA$. The bridging $\mathrm{Mn}-\mathrm{Cl}$ distances, which are in the range from 2.545 (4) to 2.574 (4) $\AA$ [22], and the Mn-O distances are in the range from 2.164 (2) to 2.173 (2) (Table 2).

The Octahedral polymers formed by the association of monomers $\left[\mathrm{Mn}(2) \mathrm{Cl}_{2}\left(\mathrm{H}_{2} \mathrm{O}\right)_{2}\right]$ are linked through two chlorine atoms giving rise to an infinite chain of formula $\left[\mathrm{Mn}(2) \mathrm{Cl}_{2} 2 \mathrm{H}_{2} \mathrm{O}\right]_{n}$. These chains are developed along the a axis at $\mathrm{z}=1 / 2$. 
The $\left[\mathrm{Mn}(2) \mathrm{Cl}_{2}\left(2 \mathrm{H}_{2} \mathrm{O}\right)\right]$ n linear chains and the $\left[\mathrm{Mn}(1) \mathrm{Cl}\left(2 \mathrm{H}_{2} \mathrm{O}\right)\right]$ isolated octahedron are interconnected of hydrogen bonds by type $\mathrm{O}-\mathrm{H} \ldots \mathrm{Cl}$ and also by the water molecules of two types of hydrogen bonds (table 4) : $\mathrm{O}-\mathrm{H} \ldots \mathrm{O}, \mathrm{O}-\mathrm{H} \ldots \mathrm{Cl}$ as illustrated in figure 3 . The lengths of the $\mathrm{N}-\mathrm{C}$ bonds are in the range between 1.510(5) and 1.526(5) $\mathrm{A}$. The C-N-C angles range from $106.1(3)$ to $111.4(3)^{\circ}$. The $\mathrm{C}-\mathrm{C}$ bonds lengths are in the region between $1.510(6)$ and $1.520(5)$.

Table. 1. Procedures for data collection and refinement of $\left[\left(\mathrm{CH}_{3} \mathrm{CH}_{2}\right)_{4} \mathrm{~N}\right] \mathrm{Mn}_{1,5} \mathrm{Cl}_{3} 4 \mathrm{H}_{2} \mathrm{O} \mathrm{Cl} 2\left(\mathrm{H}_{2} \mathrm{O}\right)$

\begin{tabular}{|c|c|}
\hline \multicolumn{2}{|c|}{ The crystallographic characteristics and conditions for data collection } \\
\hline Compound & {$\left[\left(\mathrm{CH}_{3} \mathrm{CH}_{2}\right)_{4} \mathrm{~N}\right] \mathrm{Mn}_{1,5} \mathrm{Cl}_{3} 4\left(\mathrm{H}_{2} \mathrm{O}\right) \mathrm{Cl} 2\left(\mathrm{H}_{2} \mathrm{O}\right)$} \\
\hline Habit-colour & Plate- pink \\
\hline Density & 1,55 \\
\hline Crystal system & Triclinic \\
\hline Space group & $\mathrm{P}-1$ \\
\hline z & 1 \\
\hline$\alpha(\AA)$ & $7.542(4)$ \\
\hline $\mathrm{b}(\hat{\AA})$ & $9.846(4)$ \\
\hline$c(\hat{A})$ & $13.767(6)$ \\
\hline$a\left(\left(^{\circ}\right)\right.$ & $89.951(3)$ \\
\hline$\beta\left(^{\circ}\right)$ & $89.753(3)$ \\
\hline $\mathrm{Y}\left(^{\circ}\right)$ & $81.861(3)$ \\
\hline Standard reflections & 7320 \\
\hline Reflections with $\mathrm{I}>2 \sigma(\mathrm{I})$ & 3548 \\
\hline$T$ min & 0,3736 \\
\hline$T \max$ & 0,9290 \\
\hline$R$ & 0,055 \\
\hline & \\
\hline
\end{tabular}


Table. 2. Main interatomic distances and bond angles obtained for $\left[\left(\mathrm{CH}_{3} \mathrm{CH}_{2}\right)_{4} \mathrm{~N}\right] \mathrm{Mn}_{1,5} \mathrm{Cl}_{3} 4 \mathrm{H}_{2} \mathrm{O} \mathrm{Cl} 2\left(\mathrm{H}_{2} \mathrm{O}\right)$

\begin{tabular}{|c|c|c|c|}
\hline \multicolumn{2}{|c|}{ 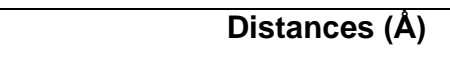 } & \multicolumn{2}{|c|}{ Angles $\left(^{\circ}\right)$} \\
\hline $\mathrm{Mn}(1)-\mathrm{Cl}(5)$ & $2.4862(9)$ & $\mathrm{O}(6)-\mathrm{Mn}(1)-\mathrm{O}(6)^{i}$ & 180.0 \\
\hline $\mathrm{Mn}(1)-\mathrm{O}(5)$ & $2.2415(12)$ & $\mathrm{O}(6)-\mathrm{Mn}(1)-\mathrm{O}(5)^{\mathrm{i}}$ & 92.5 \\
\hline $\mathrm{Mn}(1)-\mathrm{O}(6)$ & $2.2030(12)$ & $\mathrm{O}(6)^{i-} \mathrm{Mn}(1)-\mathrm{O}(5)_{\mathrm{i}}$ & 87.5 \\
\hline $\operatorname{Mn}(2)-C l(4)^{i i}$ & $2.5453(10)$ & 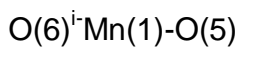 & 92.5 \\
\hline $\mathrm{Mn}(2)-\mathrm{Cl}(3)^{\mathrm{iii}}$ & $2.5670(10)$ & $\mathrm{O}(5)^{\mathrm{i}}-\mathrm{Mn}(1)-\mathrm{O}(5)$ & $180.00(6)$ \\
\hline $\mathrm{Mn}(2)-\mathrm{O}(1)$ & $2.1644(13)$ & $\mathrm{O}(6)-\mathrm{Mn}(1)-\mathrm{Cl}(5)$ & $90.89(4)$ \\
\hline $\mathrm{Mn}(2)-\mathrm{O}(2)$ & $2.1734(13)$ & $\mathrm{O}(6)^{\mathrm{i}}-\mathrm{Mn}(1)-\mathrm{Cl}(5)$ & $89.11(4)$ \\
\hline $\mathrm{Mn}(2)-\mathrm{Cl}(3)$ & $2.5725(10)$ & 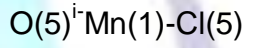 & $91.27(4)$ \\
\hline \multirow[t]{14}{*}{$\mathrm{Mn}(2)-\mathrm{Cl}(4)$} & $2.5745(10)$ & $\mathrm{O}(5)-\mathrm{Mn}(1)-\mathrm{Cl}(5)$ & $88.73(4)$ \\
\hline & & $\mathrm{O}(6)^{i}-\mathrm{Mn}(1)-\mathrm{Cl}(5)^{i}$ & $90.89(4)$ \\
\hline & & $\mathrm{O}(5)-\mathrm{Mn}(1)-\mathrm{Cl}(5)$ & $88.73(4)$ \\
\hline & & $\mathrm{O}(5)-\mathrm{Mn}(1)-\mathrm{Cl}(5)^{\mathrm{i}}$ & $91.27(4)$ \\
\hline & & $\mathrm{O}(1)-\mathrm{Mn}(2)-\mathrm{O}(2)$ & $178.65(7)$ \\
\hline & & $\mathrm{O}(1)-\mathrm{Mn}(2)-\mathrm{Cl}(4)^{\mathrm{ii}}$ & $86.57(4)$ \\
\hline & & $\mathrm{O}(2)-\mathrm{Mn}(2)-\mathrm{Cl}(4)^{\mathrm{ii}}$ & $92.11(4)$ \\
\hline & & $\mathrm{O}(1)-\mathrm{Mn}(2)-\mathrm{Cl}(3)^{\mathrm{iii}}$ & $87.56(4)$ \\
\hline & & $\mathrm{O}(2)-\mathrm{Mn}(2)-\mathrm{Cl}(3)^{\mathrm{iii}}$ & $93.76(4)$ \\
\hline & & $\mathrm{Cl}(4)^{\mathrm{ii}}-\mathrm{Mn}(2)-\mathrm{Cl}(3)^{\mathrm{iii}}$ & $174.05(4)$ \\
\hline & & $\mathrm{O}(1)-\mathrm{Mn}(2)-\mathrm{Cl}(3)$ & $94.87(4)$ \\
\hline & & $\mathrm{O}(2)-\mathrm{Mn}(2)-\mathrm{Cl}(3)$ & $85.57(4)$ \\
\hline & & $\mathrm{Cl}(4)^{\mathrm{i} i-} \mathrm{Mn}(2)-\mathrm{Cl}(3)$ & $97.22(3)$ \\
\hline & & $\mathrm{Cl}(3)^{\mathrm{iii}}-\mathrm{Mn}(2)-\mathrm{Cl}(3)$ & $84.23(3)$ \\
\hline
\end{tabular}




\begin{tabular}{|l|lr|}
\hline & O(1)-Mn(2)-Cl(4) 94.03(4) \\
\hline & O(2)-Mn(2)-Cl(4) 85.61(4) \\
\hline & $\mathrm{Cl}(4)^{\mathrm{ii}}-\mathrm{Mn}(2)-\mathrm{Cl}(4) \quad 86.38(3)$ \\
\hline & $\mathrm{Cl}(3)^{\mathrm{iii}}-\mathrm{Mn}(2)-\mathrm{Cl}(4) \quad 93.08(3)$ \\
\hline & $\mathrm{Cl}(3)-\mathrm{Mn}(2)-\mathrm{Cl}(4)$ & $170.59(4)$ \\
\hline
\end{tabular}

Symmetry codes:

(I) $-x,-y+2,-z$;

(II) $-x-y,-z+1$;

(III) $-x+1,-y,-z+1$

\begin{tabular}{|c|c|c|c|}
\hline & Distances $(\AA)$ & \multicolumn{2}{|c|}{ Angles $\left(^{\circ}\right)$} \\
\hline$N(1)-C(1)$ & $1.526(5)$ & $C(2)-N(1)-C(3)$ & $111.3(3)$ \\
\hline$N(1)-C(2)$ & $1.510(5)$ & $C(2)-N(1)-C(4)$ & $111.4(3)$ \\
\hline$N(1)-C(3)$ & $1.516(5)$ & $C(3)-N(1)-C(4)$ & $107.2(3)$ \\
\hline$N(1)-C(4)$ & $1.519(5)$ & $C(2)-N(1)-C(1)$ & $106.1(3)$ \\
\hline$C(1)-C(6)$ & $1.513(6)$ & $C(3)-N(1)-C(1)$ & $110.5(3)$ \\
\hline $\mathrm{C}(2)-\mathrm{C}(8)$ & $1.515(5)$ & $C(4)-N(1)-C(1)$ & $110.3(3)$ \\
\hline$C(3)-C(7)$ & $1.521(4)$ & $N(1)-C(2)-C(8)$ & $113.7(3)$ \\
\hline \multirow[t]{3}{*}{$C(4)-C(5)$} & $1.511(6)$ & $N(1)-C(3)-C(7)$ & $115.3(3)$ \\
\hline & & $C(6)-C(1)-N(1)$ & $115.1(3)$ \\
\hline & & $C(5)-C(4)-N(1)$ & $114.6(3)$ \\
\hline
\end{tabular}


Table. 3. Final atomic coordination, Ueq and temperature factors (Uiso for $\mathrm{H}$ atoms) of $\left[\left(\mathrm{CH}_{3} \mathrm{CH}_{2}\right)_{4} \mathrm{~N}\right] \mathrm{Mn}_{1,5} \mathrm{Cl}_{3} 4 \mathrm{H}_{2} \mathrm{O} \mathrm{Cl} 2\left(\mathrm{H}_{2} \mathrm{O}\right)$

\begin{tabular}{|c|c|c|c|c|}
\hline Atomes & $\mathbf{x} / \mathbf{a}$ & $y / b$ & $z / c$ & $U_{\text {eq }}$ et $U_{\text {iso* }}$ \\
\hline $\mathrm{Mn}(1)$ & 0.0000 & 1.0000 & 0.0000 & $0.0265(2)$ \\
\hline $\mathrm{Mn}(2)$ & $0.2468(6)$ & $0.0028(5)$ & $0.4968(4)$ & $0.0261(2)$ \\
\hline $\mathrm{Cl}(3)$ & $0.4726(11)$ & $0.1740(9)$ & $0.4780(7)$ & $0.0325(2)$ \\
\hline $\mathrm{Cl}(4)$ & $0.0331(11)$ & $-0.1678(9)$ & $0.54558(7)$ & $0.0310(2)$ \\
\hline $\mathrm{Cl}(5)$ & $-0.0149(13)$ & $1.0439(11)$ & $0.1778(6)$ & $0.0393(3)$ \\
\hline $\mathrm{Cl}(6)$ & $0.5396(12)$ & $0.8165(10)$ & $0.1884(7)$ & $0.0355(2)$ \\
\hline $\mathrm{O}(1)$ & $0.2559(2)$ & $-0.0565(12)$ & $0.3454(8)$ & $0.0519(9)$ \\
\hline $\mathrm{O}(2)$ & $0.23139(2)$ & $0.0650(12)$ & $0.6484(8)$ & $0.0373(7)$ \\
\hline $\mathrm{O}(3)$ & $0.6282(2)$ & $0.2503(12)$ & $0.2673(8)$ & $0.0493(8)$ \\
\hline $\mathrm{O}(4)$ & $0.4713(2)$ & $0.1309(12)$ & $0.1146(8)$ & $0.0485(7)$ \\
\hline $\mathrm{O}(5)$ & $0.1747(2)$ & $1.1650(12)$ & $-0.0149(8)$ & $0.0379(6)$ \\
\hline $\mathrm{O}(6)$ & $0.2469(2)$ & $0.8534(12)$ & $0.0176(8)$ & $0.0379(6)$ \\
\hline $\mathrm{N}$ & $-0.0991(4)$ & $0.4848(3)$ & $0.7481(2)$ & $0.0275(6)$ \\
\hline$C(1)$ & $-0.2321(6)$ & $0.5515(4)$ & $0.6729(3)$ & $0.0400(9)$ \\
\hline$C(2)$ & $-0.0157(6)$ & $0.6002(4)$ & $0.7933(3)$ & $0.0432(10)$ \\
\hline$C(3)$ & $-0.1940(6)$ & $0.4088(4)$ & $0.8236(3)$ & $0.0408(9)$ \\
\hline$C(4)$ & $0.0413(6)$ & $0.3804(4)$ & $0.6998(3)$ & $0.0421(10)$ \\
\hline$C(5)$ & $0.1552(7)$ & $0.4395(5)$ & $0.6246(4)$ & $0.0538(12)$ \\
\hline$C(6)$ & $-0.3340(7)$ & $0.4535(5)$ & $0.6190(4)$ & $0.0544(12)$ \\
\hline$C(7)$ & $-0.3410(2)$ & $0.4965(12)$ & $0.8805(8)$ & $0.0552(12)$ \\
\hline$C(8)$ & $0.1230(2)$ & $0.5528(12)$ & $0.8699(8)$ & $0.0639(14)$ \\
\hline $\mathrm{H} 1 \mathrm{~A}$ & -0.1676 & 0.5995 & 0.6259 & 0.048 \\
\hline H1B & -0.3178 & 0.6195 & 0.7054 & 0.048 \\
\hline $\mathrm{H} 2 \mathrm{~A}$ & -0.1096 & 0.6650 & 0.8225 & 0.052 \\
\hline $\mathrm{H} 2 \mathrm{~B}$ & 0.0402 & 0.6480 & 0.7425 & 0.052 \\
\hline $\mathrm{H} 3 \mathrm{~A}$ & -0.2458 & 0.3363 & 0.7914 & 0.049 \\
\hline H3B & -0.1056 & 0.3657 & 0.8692 & 0.049 \\
\hline $\mathrm{H} 4 \mathrm{~A}$ & 0.1192 & 0.3354 & 0.7496 & 0.050 \\
\hline H4B & -0.0186 & 0.3109 & 0.6690 & 0.050 \\
\hline H5A & 0.2401 & 0.3674 & 0.5976 & 0.081 \\
\hline H5B & 0.2179 & 0.5067 & 0.6545 & 0.081 \\
\hline $\mathrm{H} 5 \mathrm{C}$ & 0.0799 & 0.4820 & 0.5738 & 0.081 \\
\hline $\mathrm{H} 6 \mathrm{~A}$ & -0.4141 & 0.5039 & 0.5735 & 0.082 \\
\hline H6B & -0.4016 & 0.4073 & 0.6645 & 0.082 \\
\hline $\mathrm{H} 6 \mathrm{C}$ & -0.2511 & 0.3872 & 0.5848 & 0.082 \\
\hline H7A & -0.3931 & 0.4402 & 0.9265 & 0.083 \\
\hline H7B & -0.4317 & 0.5375 & 0.8366 & 0.083 \\
\hline $\mathrm{H} 7 \mathrm{C}$ & -0.2911 & 0.5674 & 0.9144 & 0.083 \\
\hline
\end{tabular}




\begin{tabular}{|l|l|l|l|l|}
\hline H8A & 0.0683 & 0.5074 & 0.9213 & 0.096 \\
\hline H8B & 0.2183 & 0.4905 & 0.8413 & 0.096 \\
\hline H8C & 0.1705 & 0.6308 & 0.8957 & 0.096 \\
\hline H1A & 0.3406 & -0.0934 & 0.3178 & $0.047(2)$ \\
\hline H2A & 0.3152 & 0.1032 & 0.6798 & $0.050(2)$ \\
\hline H3A & 0.7481 & 0.2017 & 0.2565 & $0.10(2)$ \\
\hline H3B & 0.5766 & 0.2427 & 0.3140 & $0.10(2)$ \\
\hline H4A & 0.5061 & 0.1853 & 0.1654 & $0.050(2)$ \\
\hline H4B & 0.4900 & 0.0567 & 0.1297 & $0.050(2)$ \\
\hline H5A & 0.2445 & 1.1816 & 0.0299 & $0.09(2)$ \\
\hline H5B & 0.2409 & 1.1633 & -0.0775 & $0.13(3)$ \\
\hline H6A & 0.3126 & 0.8561 & 0.0725 & $0.059(2)$ \\
\hline H6B & 0.3306 & 0.8490 & -0.0210 & $0.050(2)$ \\
\hline
\end{tabular}

Table.4. Bond lengths $(\AA)$ and bond angles $\left(^{\circ}\right)$ in the hydrogen bonding scheme of $\left[\left(\mathrm{CH}_{3} \mathrm{CH}_{2}\right)_{4} \mathrm{~N}\right] \mathrm{Mn}_{1,5} \mathrm{Cl}_{3} 4 \mathrm{H}_{2} \mathrm{O} \mathrm{Cl}$ 2( $\left.\mathrm{H}_{2} \mathrm{O}\right)$

\begin{tabular}{|c|c|c|c|c|}
\hline D-H...A & $d(D-H)(\AA)$ & $d(H \ldots A)(\AA ̊)$ & $d(D \ldots A)(\AA)$ & $\angle \mathrm{D}-\mathrm{H} \ldots \mathrm{A}\left(\mathbf{(}^{\circ}\right)$ \\
\hline O1-H1A...Cl6 & 0.78 & 2.41 & $3.165(15)$ & 161.3 \\
\hline O1-H1B..Cl5 & 0.94 & 2.33 & $3.152(14)$ & 146.3 \\
\hline O2-H2A...CI6" & 0.89 & 2.32 & $3.161(14)$ & 157.2 \\
\hline O2-H2B...Cl5"II' & 0.77 & 2.41 & $3.161(15)$ & 165.2 \\
\hline O3-H3A...Cl5 ${ }^{\mathrm{IV}}$ & 0.97 & 2.45 & $3.364(15)$ & 157.5 \\
\hline O3-H3B...Cl3 ${ }^{v}$ & 0.76 & 2.51 & $3.251(15)$ & 165.6 \\
\hline O4-H4A...O3 ${ }^{v}$ & 0.94 & 1.85 & 2.761 & 163.3 \\
\hline O4-H4B...Cl6 & 0.75 & 2.48 & $3.229(15)$ & 176.4 \\
\hline O5-H5A...O $4^{\prime}$ & 0.84 & 2.08 & 2.850 & 152.1 \\
\hline O5-H5B...Cl6" & 0.99 & 2.28 & $3.231(14)$ & 161.2 \\
\hline O6-H6A...Cl6 & 0.91 & 2.34 & $3.216(14)$ & 163.2 \\
\hline O6-H6B...O4 $4^{v 11}$ & 0.82 & 2.00 & $2.813(2)$ & 171.3 \\
\hline
\end{tabular}

Symmetry codes:
(i) $x, y-1, z$;
(ii) $-x+1,-y+1, z$
(iii) $-x,-y+1,-z+1$;
(iv) $\mathrm{x}+1,-\mathrm{y}+1, \mathrm{z}$;
(v) $x, y, z$;
(vi) $-x+1,-y+2,-z$;
(vii) $-x+1,-y+1,-z$. 


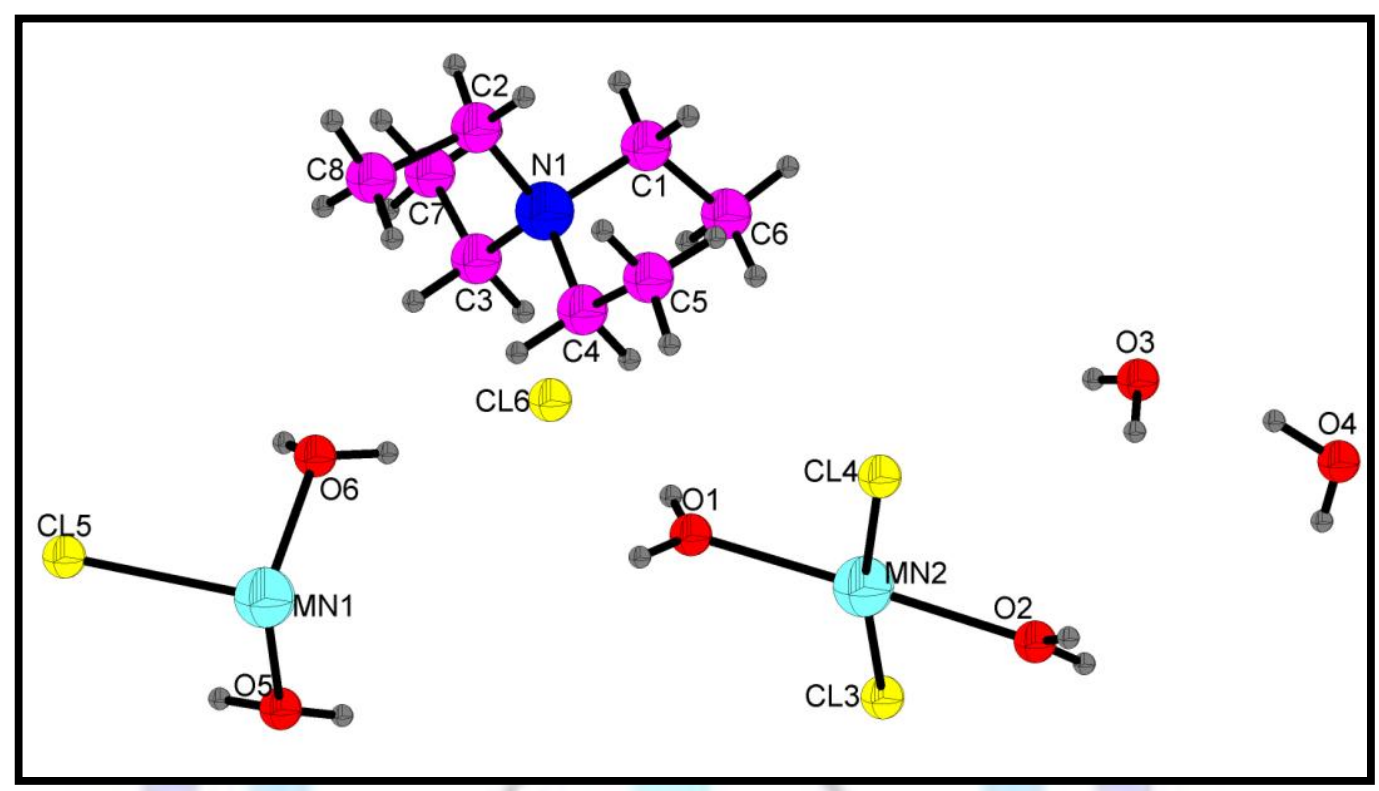

Figure. 1. The asymmetric unit of $\left[\left(\mathrm{CH}_{3} \mathrm{CH}_{2}\right)_{4} \mathrm{~N}\right] \mathrm{Mn}_{1,5} \mathrm{Cl}_{3} 4 \mathrm{H}_{2} \mathrm{O} \mathrm{Cl} 2\left(\mathrm{H}_{2} \mathrm{O}\right)$

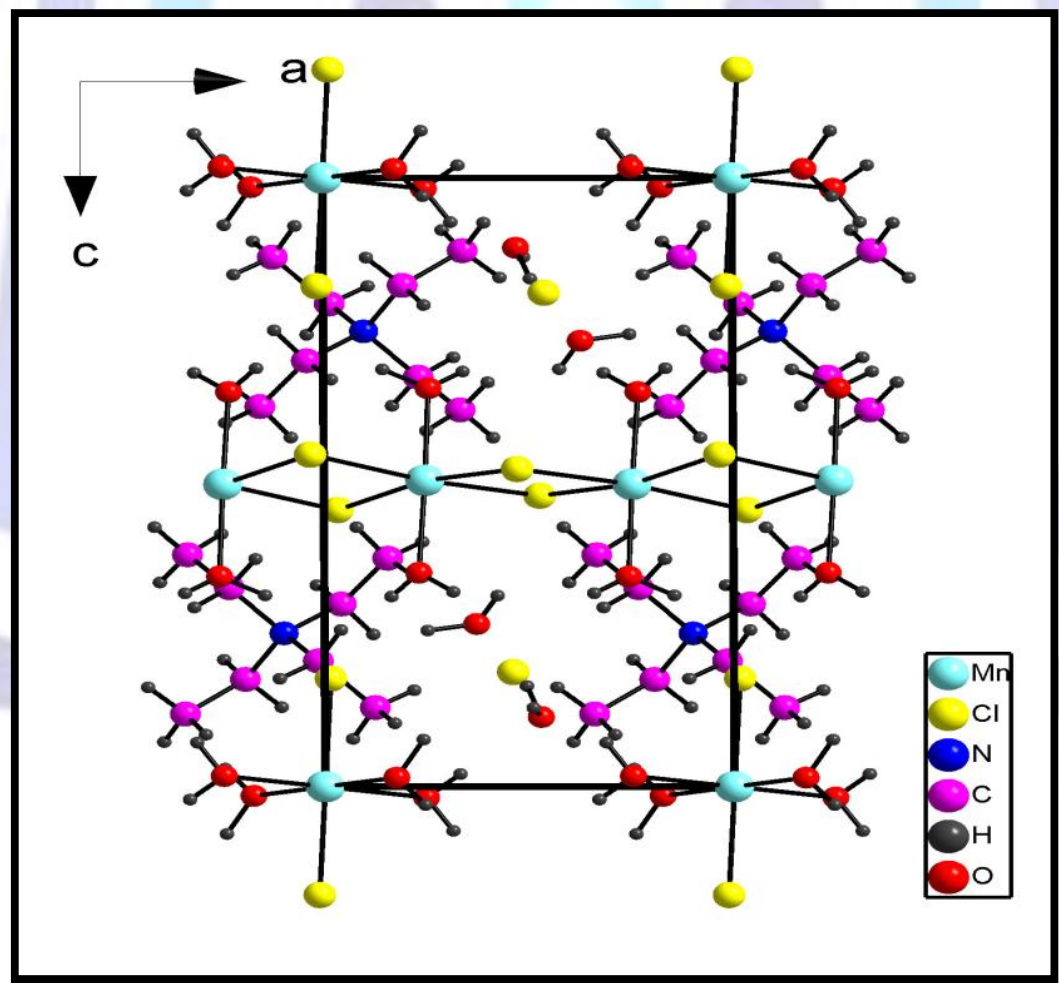

Figure. 2. Projection along the $b$ axis of the atomic arrangement of $\left[\left(\mathrm{CH}_{3} \mathrm{CH}_{2}\right)_{4} \mathrm{~N}\right] \mathrm{Mn}_{1,5} \mathrm{Cl}_{3} 4 \mathrm{H}_{2} \mathrm{O} \mathrm{Cl} 2\left(\mathrm{H}_{2} \mathrm{O}\right)$ 


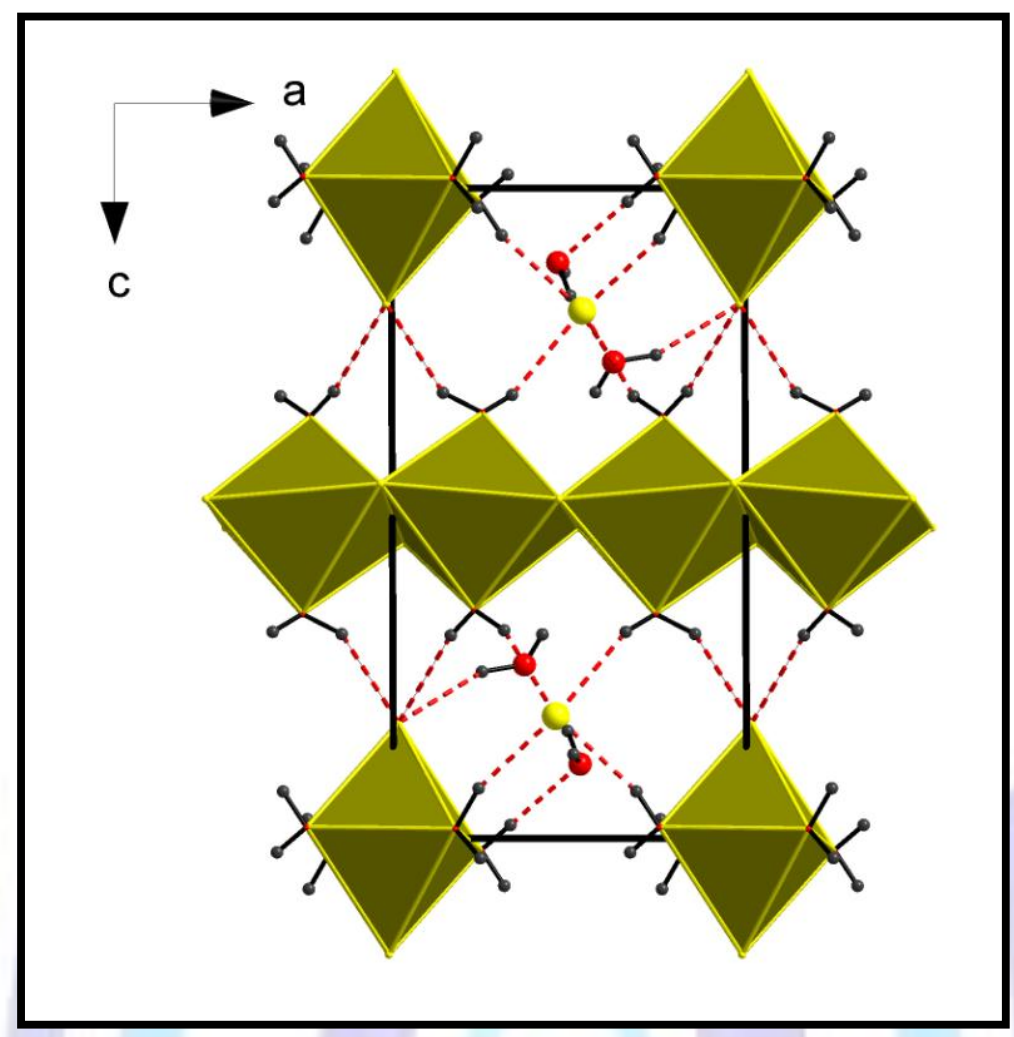

Figure. 3. Projection along the $b$ axis of the inorganic arrangement of $\left[\left(\mathrm{CH}_{3} \mathrm{CH}_{2}\right)_{4} \mathrm{~N}\right] \mathrm{Mn}_{1,5} \mathrm{Cl}_{3} 4 \mathrm{H}_{2} \mathrm{O} \mathrm{Cl} 2\left(\mathrm{H}_{2} \mathrm{O}\right)$

\section{2. Vibrational analysis}

\section{2. 1. The tetraethylammonium cation vibrations}

Numerous functional and skeletal groups such as $\mathrm{CH}_{2}, \mathrm{CH}_{3}, \mathrm{~N}-\mathrm{C}, \mathrm{C}-\mathrm{C}, \mathrm{NC}_{4}$ are present in tetraethylammonium cation. These groups are manifested in IR and Raman spectra in different range with different intensity are given in Figs 4,5.

\section{*Methyl vibrations}

The asymmetric and symmetric $\mathrm{CH}_{3}$ stretching vibrations are usually observed in the region $3000-2850 \mathrm{~cm}^{-1}$ [23]. The weak band at $3003 \mathrm{~cm}^{-1}$ in IR spectrum is attributed to the asymmetric stretching $\mathrm{V}_{\mathrm{as}}\left(\mathrm{CH}_{3}\right)$ vibration. The Raman counterpart is located as a very strong band at $2998 \mathrm{~cm}^{-1}$. The symmetric stretching mode $\mathrm{V}_{\text {as }}\left(\mathrm{CH}_{3}\right)$ is observed as shoulder band at $2897 \mathrm{~cm}^{-1}$ in Raman spectrum. In IR spectrum this mode appears as a very weak intensity band at the $2965 \mathrm{~cm}^{-1}$. The asymmetric and symmetric bending mode of methyl group generally appears in the region 1550-1410 and $1400-1340 \mathrm{~cm}^{-1}$ respectively. In the present case, the medium IR band at $1494 \mathrm{~cm}^{-1}$ is assigned to $\mathrm{CH}_{3}$ asymmetric bending mode and the corresponding Raman band appears as a strong band at $1462 \mathrm{~cm}^{-1}$. The symmetric bending mode $\delta_{S}\left(\mathrm{CH}_{3}\right)$ is located at $1402 \mathrm{~cm}^{-1}$ as a weak band in the IR spectrum and as a very weak band at $1387 \mathrm{~cm}^{-1}$ in Raman spectrum. The methyl rocking vibration is observed as a weak band at $997 \mathrm{~cm}^{-1}$ in IR spectrum and at $1001 \mathrm{~cm}^{-1}$ as a medium one in Raman spectrum.

\section{*Methylene group vibrations}

The wavenumber of the $\mathrm{CH}_{2}$ vibrational modes depend on its immediate environment. The stretching modes of the $\mathrm{CH}_{2}$ group usually occur in the region $3100-2800 \mathrm{~cm}^{-1}$ [24]. In the title compound, the $\mathrm{CH}_{2}$ asymmetric and symmetric stretching modes are observed in Raman spectrum at $2946 \mathrm{~cm}^{-1}$ as very strong band and at $2824 \mathrm{~cm}^{-1}$ as very weak band respectively. In IR spectrum, these modes are probably masked by the broad band around $2900 \mathrm{~cm}^{-1}$. The wagging, twisting and the rocking modes of the $\mathrm{CH}_{2}$ group were observed and assigned.

\section{${ }^{*} \mathrm{NC}_{4}$ group vibrations}

The primitive unit cell of the title compound contains one tetrapropylammonium $\left(\mathrm{NC}_{4}\right)^{+}$cation not coupled with the inorganic parts as revealed by the X-Ray diffraction. Then, it is convenient as a first approach to consider the $\mathrm{NC}_{4}$ core of the isolated cation with $\mathrm{Td}$ symmetry and therefore exhibits four normal modes. According to the literature, the vibrations related to $\mathrm{NC}_{4}$ group shown in tetrapropylammonium cation are described as: symmetric stretching mode $\mathrm{v}_{1}(\mathrm{~A})$ to be 
found at $752 \mathrm{~cm}^{-1}$, asymmetric stretching mode $V_{3}\left(F_{2}\right)$ located at $955 \mathrm{~cm}^{-1}$, asymmetric bending mode $V_{4}\left(F_{2}\right)$ observed at $455 \mathrm{~cm}^{-1}$ and the symmetric bending mode $V_{2}\left(F_{2}\right)$ at $372 \mathrm{~cm}^{-1}$ [25-26]. In our case the very weak Raman band appeared at $1044 \mathrm{~cm}^{-1}$ is related to the $V_{3}$ mode. His counterpart appears in IR spectrum as weak band at $1011 \mathrm{~cm}^{-1}$. The week band observed in Raman spectrum at $787 \mathrm{~cm}^{-1}$ and the shoulder one at $790 \mathrm{~cm}^{-1}$ in IR spectrum arises from the symmetric stretching mode $\mathrm{v}_{1}\left(\mathrm{NC}_{4}\right)$. The band assigned to the symmetric bending modes of $\mathrm{NC}_{4}$ core of the isolated cation is observed in Raman spectrum at $325 \mathrm{~cm}^{-1}$ with no conteroart in IR spectrum. The asymmetric band $\mathrm{v}_{2}\left(\mathrm{NC}_{4}\right)$ is not observed in IR spectrum and probably masked by the very intense band at $417 \mathrm{~cm}^{-1}$ assigned in Raman spectrum. It is interest to note that the vibrational mode of the $\mathrm{NC}_{4}$ group do not deviate much from their expected values, suggesting that the interaction of this group with the environment is not strong. On the other hand, we note that our assignment of $\mathrm{NC}_{4}$ agree well with the previous reported vibrational studies of the tetrapropylammonium salts [27].

\section{${ }^{*} \mathrm{~N}-\mathrm{C}, \mathrm{C}-\mathrm{C}, \mathrm{C}-\mathrm{C}-\mathrm{C}$ and $\mathrm{C}-\mathrm{C}-\mathrm{N}$ group of vibrations}

The absorption bands arising from N-C symmetric stretching vibrations are observed in the wavenumber region 850-1150 $\mathrm{cm}^{-1}$. In the present crystal the strong Raman band at $1117 \mathrm{~cm}^{-1}$ is assigned to this mode. His IR counterpart is identified at $1174 \mathrm{~cm}^{-1}$. The corresponding theoretical value is at $1127 \mathrm{~cm}^{-1}$. The absorption bands arising from the C-N-C stretching mode is observed in IR spectrum at $1011 \mathrm{~cm}^{-1}$ and in Raman spectrum at 1117,745 and $676 \mathrm{~cm}^{-1}$. The weak bands appeared at 1150 and $1146 \mathrm{~cm}^{-1}$ in IR spectrum and at 1173 and $1151 \mathrm{~cm}^{-1}$ in Raman are related to C-C stretching mode. The C-C-C vibrational bands have been identified and assigned. Table 5 presented a detailed assignment of all observed band related to organic cation.

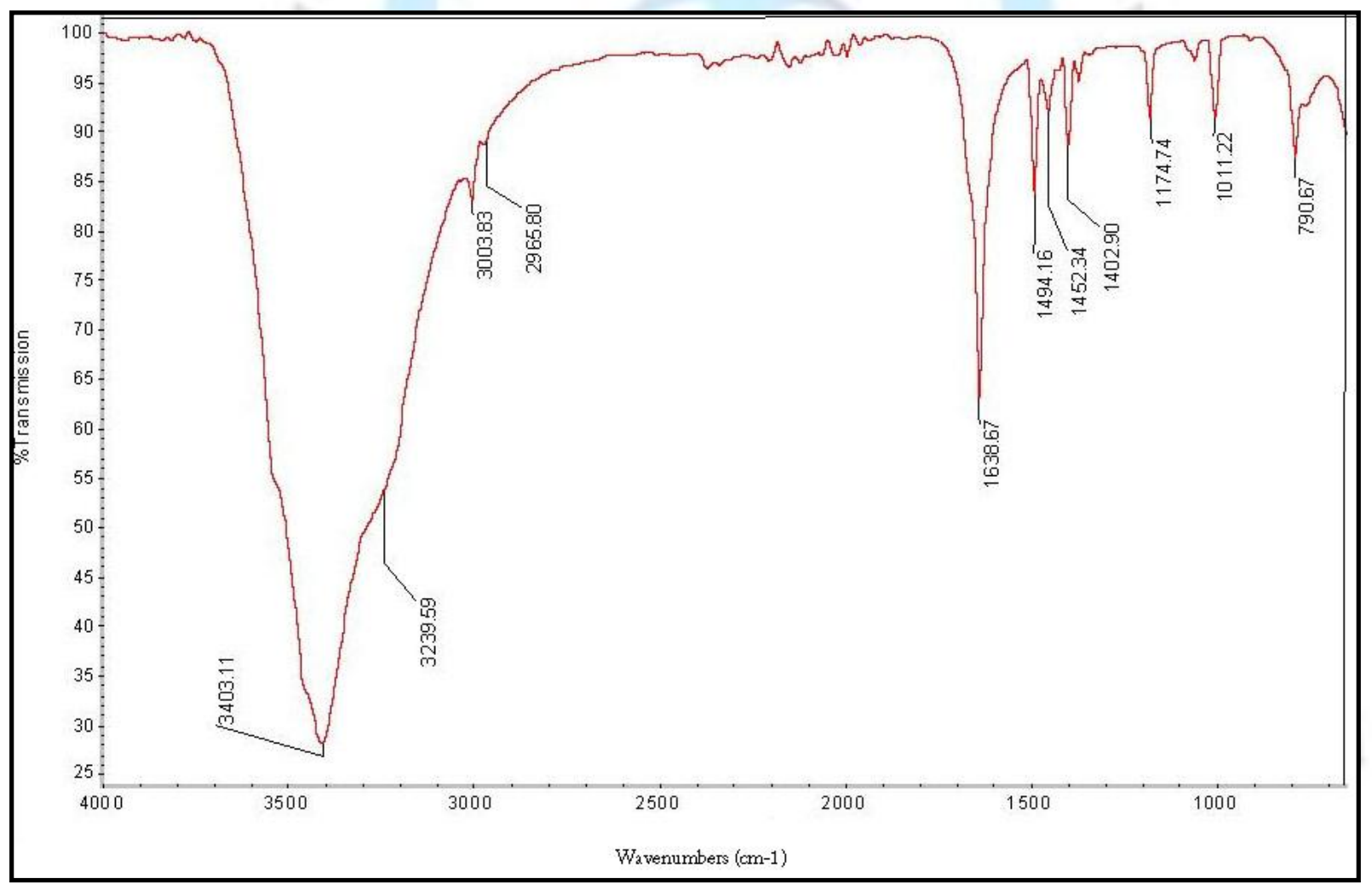

Figure.4. IR spectrum of $\left[\left(\mathrm{CH}_{3} \mathrm{CH}_{2}\right)_{4} \mathrm{~N}\right] \mathrm{Mn}_{1,5} \mathrm{Cl}_{3} 4 \mathrm{H}_{2} \mathrm{O} \mathrm{Cl} 2\left(\mathrm{H}_{2} \mathrm{O}\right)$ 


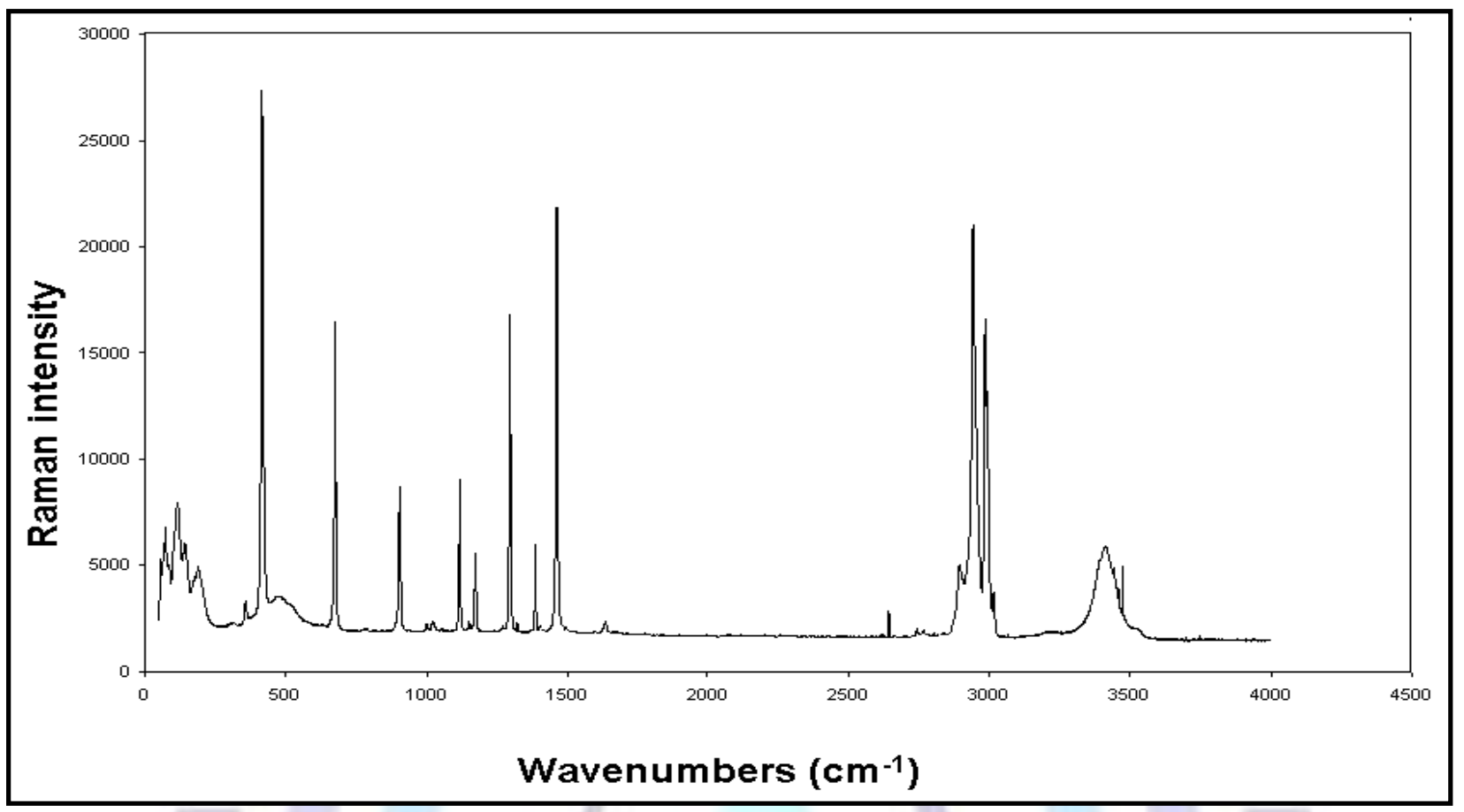

Figure. 5. Raman spectrum of $\left[\left(\mathrm{CH}_{3} \mathrm{CH}_{2}\right)_{4} \mathrm{~N}\right] \mathrm{Mn}_{1,5} \mathrm{Cl}_{3} 4 \mathrm{H}_{2} \mathrm{O} \mathrm{Cl} 2\left(\mathrm{H}_{2} \mathrm{O}\right)$

\section{Summary}

Crystals of a hybrid material, $\left[\left(\mathrm{CH}_{3} \mathrm{CH}_{2}\right){ }_{4} \mathrm{~N}\right] \mathrm{Mn}_{1,5} \mathrm{Cl}_{3} 4 \mathrm{H}_{2} \mathrm{O} \mathrm{Cl} 2\left(\mathrm{H}_{2} \mathrm{O}\right)$, have been prepared by slow evaporation of aqueous solution $\left(\mathrm{CH}_{3} \mathrm{CH}_{2}\right)_{4} \mathrm{NOH}, \mathrm{MnCl}_{2}$. and concentrated $\mathrm{HCl}$ at room temperature and characterized by means of single-crystal X-ray diffraction, FT-IR and Raman vibrational study. The structure consists of strong two dimensional character based on sheets of $\left[\mathrm{Mn}(2) \mathrm{Cl}_{2}\left(2 \mathrm{H}_{2} \mathrm{O}\right)\right] \mathrm{n}$ and $\left[\mathrm{Mn}(1) \mathrm{Cl}\left(2 \mathrm{H}_{2} \mathrm{O}\right)\right]$ are interconnected of hydrogen bonds by type $\mathrm{O}-$ $\mathrm{H} \ldots \mathrm{Cl}$ and also by the water molecules of two types of hydrogen bond $\mathrm{O}-\mathrm{H} \ldots \mathrm{O}, \mathrm{O}-\mathrm{H} \ldots \mathrm{Cl}$. The planes of inorganic groups alternated with planes of the organic cations.

\section{References:}

[1] Braga, D., Desiraju, G.R., Miller, J.S., Orpen, A.G., Price, S.L., Cryst. Eng. Commun. 4 (2002) 500.

[2] Desiraju, G.R., Angew. Chem. Int. Ed. Engl. 34 (1995) 2311.

[3] Desiraju, G.R., J. Mol. Struct. 656 (2003) 5.

[4] Mitzi, D.B.,Prog. Inorg. Chem. 48 (1999) 1.

[5] Lacroix, P.G. , Clement, R. , Nakatani, K., Delaire, J.A., Zyss, J., Ledoux,I., Science 263 (1994) 658.

[6] De Zea Bermudez, V., Carlos, L.D., Duarte, M.C. , Silva, M.M. , Silva, C.J., Smith, M.J.,Assunc,ao,

M., Alcacer, L. ,J. Alloys Compd. 21 (1998) 275.

[7] Carlos, L.D., Sa Ferreira, R.A., de Zea Bermudez, V., Ribeiro, S.J.L., Adv. Funct. Mater. 2 (2001) 111.

[8] Kato, Y., Ichii, D., Ohashi, K., Kunugita, H., Ema, K. , Tanaka, K. , Takahashi, T. , Kondo, T.,Solid State

Commun. 128 (2003) 15.

[9] El-Korashy, A., BriK, M.G., Solid State Commun. 135 (2005) 298.

[10] Ben Rhaiem, A., Hlel, F., Guidara, K., Gargouri, M. J. Alloys Compd. 463 (2008) 440.

[11] Cavellec, M.R., Albinet, C., Greneche, J.M., Ferey, G., J. Mater. Chem. 11 (2001) 3166.

[12] Lach, G., Laskowski, L., Kityk, I.V., Kapustianyk, V., Rudyk, V. Shchur, Ya. , Tkaczyk, S.,J.Swiatek,

J., Piasecki, M., J. Non-Crystalline Solid 353 (2007) 4353.

[13] Hiroyuki, H., Mashiyama, H., Koshiji, N., Acta Cryst. B 45 (1989) 467. 
[14] Dhouib, I., Guionneau, P., Pechev, S., Mhiri, T., Elaoud, Z., European journal of chemistry. 4 (2) (2013) 117.

[15] Dhouib, I., Al-Juaid, S., Mhiri, T., Elaoud, Z., Crystal Structure Theory and Applications. 2 (2013) 8.

[16] Dhouib , I., Elaoud , Z., Mhiri , T., Daoud, A.,J Chemical Crystallograhy, 42,5 (2012) 513.

[17] Muller, E.A., Cannon, R.J., Sarjeant, A.N., Ok, K.M., Halasyamani, P.S., Norquist, A.J., Cryst. Growth Des. 5 (2005) 1913.

[18] Nonius, Kappa CCD Program Software, Nonius BV, Delft, The Netherlands,1998.

[19] Farrugia, L.J., J. Appl. Cystallogr 32 (1999) 837.

[20] Sheldrick, G.M. ,SHELXS-97 Programs for Crystal Solution. University of Göttingen,Germany, 1997.

[21] Sheldrick, G.M., SHELXL-97 Programs for Crystal Structure Refinement. University of Göttingen, Germany, 1997.

[22] J.-Z., Wu, S., Tanase, E., Bouwman, J., Reedijk, A.M., Mills, A.L., Spek, Inorg. Chim. Acta 351 (2003) 278.

[23] Rui-Zhou, Z., Xiao-Hong, L., Xian-Zhou, Z., Chin. J. Struct. Chem, 31 (2012) 1395.

[24] Karabacak, M., Cinar, Z. , Kurt, M., Sudha, S., Sundaraganesan, N., Spectrochim. Acta A, 85 (2012) 179.

[25] Edsall, J.T., J. Chem. Phys, 5 (1937) 225.

[26] Gosniowska, M., Ciunik, Z., Bator, G., Jakubas, R., J. Mol. Struct, 555 (2000)243.

[27] Hajlaoui, S., Chaabane, I., Oueslati, A., Guidara, K., Bulou, A., Spectrochim. Acta A.117 (2014) 225.

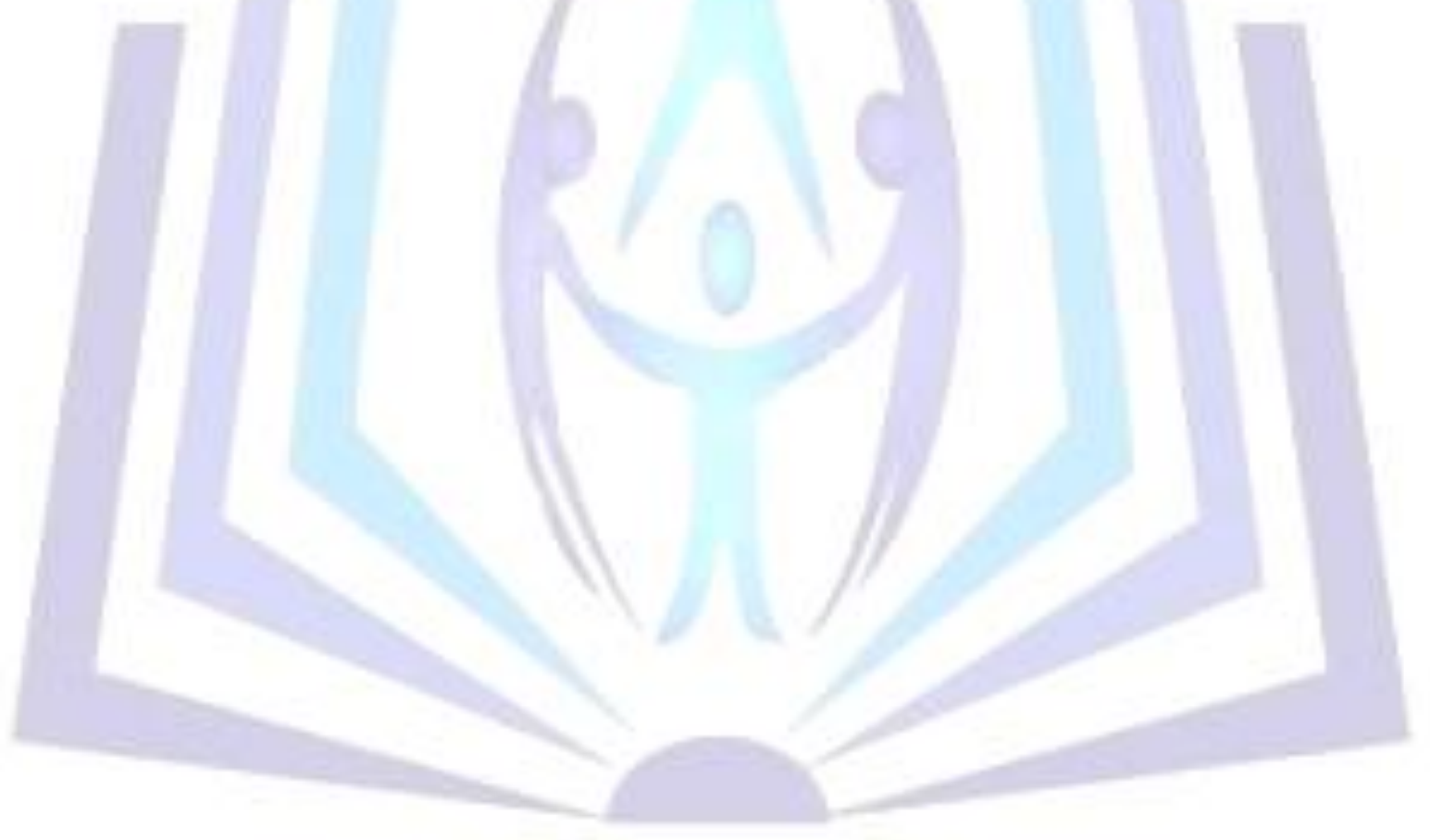

